Research Article

\title{
Financial Distress Warning: An Evaluation System including Ecological Efficiency
}

\author{
Shuang Wu, ${ }^{1}$ Hui Zhang $\mathbb{D}^{1}{ }^{1}$ Yuan Tian, ${ }^{2}$ and Liyuan Shi $\mathbb{D}^{2}$ \\ ${ }^{1}$ College of Economics and Management, Nanjing Forestry University, Nanjing, Jiangsu 210037, China \\ ${ }^{2}$ College of Business, Beijing Union University, Beijing 100025, China \\ Correspondence should be addressed to Hui Zhang; zhanghui@njfu.edu.cn
}

Received 26 May 2021; Revised 20 June 2021; Accepted 5 July 2021; Published 13 July 2021

Academic Editor: Daqing Gong

Copyright (c) 2021 Shuang Wu et al. This is an open access article distributed under the Creative Commons Attribution License, which permits unrestricted use, distribution, and reproduction in any medium, provided the original work is properly cited.

This article established an evaluation system including ecological efficiency that can provide a more accurate financial distress warning for companies. Based on the data of listed companies, Data Envelopment Analysis (DEA) is applied to evaluating the business efficiency, financial efficiency, financing efficiency, human capital efficiency, and ecological efficiency, and the accuracy of the evaluation system that includes ecological efficiency is measured by artificial neural networks (ANNs). Besides, the logit model is applied to test the results. Our experiments indicate that participating in ecological efficiency improves the evaluation system of financial distress warnings, and its accuracy is much better than the traditional evaluation system in the long run. The logit model confirms the essential of ecological indicators in financial distress warning, and the behavior of observing environmental regulation will prevent enterprises from getting into financial distress. Finally, suggestions on improving green finance and promoting technological innovation are propounded, in which technological innovation (TI) is the core of an enterprise's competitiveness, and green finance can accelerate that process.

\section{Introduction}

Environmental regulation (ER) is a popular method both to reduce pollution and protect public health. In recent years, it has been introduced actively in China, to alleviate the pollution that is mainly brought by industry. It is both a chance and a challenge for firms that are influenced by ER. On one hand, the form of environmental regulation in China was ecological compensation supported by the governments, and it would promote local firms to put efforts into industrial transformation and technological innovation in order. On the other hand, it was difficult for China to develop a fullequipped market in the field of environmental protection, which is potential trouble for firms. As a result, a firm that failed to realize the goal of green transform in the short run would be likely to face financial distress. Chinese industry was not yet on the path towards sustainable growth [1], and the study on the relationship between ER and regional green growth performance (RGGP) has always been extensively discussed in China. Technological innovation (TI) was supposed as a bridge for linking ER and RGGP [2], and it positively predicted financial performance [3]. The causality between environmental performance and financial performance was inverse in the short run and the long run [4]. Financial performance promotes environmental performance in the short run, while environmental performance feeds financial performance in the long run, in which environmental performance is believed to have a positive effect on business competitiveness [5].

During enterprise management, financial distress usually happens when a firm failed to pay the debt by cash flows, and the firm would face the risk of going bankrupt. The event of financial distress or bankruptcy financial distress may be affected by various factors, and it is supposed to be predictable, as the situation must be aggravating step by step instead of a burst. It would be helpful for firms to check the situation in time if an efficient and accurate warning model was given. The warning for financial distress distributes not only to the interests of investors but also to the regulation of the capital market. 
Previous research studies focus on the way in which ER influences financial performance. Based on data collected from managers and customers of equipment manufacturing organizations, Zameer et al. [6] explored that pressure from regulation positively influenced green production, by using covariance-based structural equation modeling (CBSEM). Jin et al. [7] showed that ER negatively influenced the improvement of China's green total factor efficiency (GTFE) of industrial water resources, and there were regional, economic, and industrial structure differences in the effect of technological innovation on the GTFE of industrial water resources. Shen et al. [8] indicated that the influence of ER on the environmental total factor productivity (ETFP) in different industries was heterogeneous. Besides, public funds and fiscal incentives were confirmed to incentivize eco-innovation [9-11], and green growth was mainly driven by green utility model patents when state-owned enterprises (SOEs) had a close relationship with the government [12].

Extant works of literature have investigated the warning of financial distress and bankruptcy, and financial data reported in the financial statement is widely used for financial distress warnings [12]. Methods for financial distress warning usually include logit model, support vector machine (SVM) $[13,14]$, partial least squares (PLS) [14], and artificial neural networks (ANNs) $[15,16]$.

The objective of this study is to establish an indicator system that includes ecological efficiency and to examine the ability of the modified indicator system in the Chinese context. It is designed to maximize the warning accuracy of financial distress and to identify the state of distressed firms by ANNs. Moreover, the logit model is compared. This study aims to answer the following questions. (1) What is the optimal time horizon of data for the warning? (2) Does ecological efficiency matter in the warning system of financial distress?

According to the relationship between ER, financial performance, and environmental performance, as well as the Porter hypothesis, our theoretic framework and hypothesis are as follows [17-19].

The relationship between ER, financial performance, and environmental performance should be treated separately in the short run and the long run. In the short run, the conduct of ER directs enterprises to alleviate pollution and protect the ecology. The regulation includes shutting down the heavy industry, applying clean energy, and adjusting the industrial structure. All such command has a negative influence on financial performance, as the transformation costs a lot during the initial period. Our first hypothesis is that ER has a negative impact on the financial performance of enterprises in the short run.

According to the Porter hypothesis [20], ER contributes to technique improvement (TI), and TI can promote an enterprise's business competitiveness. In that way, the ER improves financial performance indirectly. As ecological modernization theory [21] assumes, an enterprise's green growth may be promoted by TI-driven ER, but ER is uncertain of bringing green growth. The relationship between financial performance and environmental performance confirms that assumption. It is indisputable that ER improves environmental performance, and a healthy financial performance devotes a lot to the green transformation of enterprises. Our second hypothesis is, that ER has a positive impact on the financial performance of enterprises in the long run (Figure 1).

\section{Materials and Methods}

\subsection{Efficiency Evaluation for Enterprises}

2.1.1. Method: DEA. The method of Data Envelopment Analysis (DEA) is applied to the evaluation of the efficiency of enterprises. DEA adepts well in the study of multiple input-output, and the CCR (Charnes, Cooper, and Rhodes) model [22] is a simple one among the many forms of DEA.

The following model explains the basic design of DEA. Suppose there are $n$ DMU, and each DMU has its $m$ input and $s$ output. Let variable $x_{i j}(i=1, \ldots, m ; j=1, \ldots, n)$ be the $i$ input of $j$ DMU, and let variable $y_{r j}(r=1, \ldots, s ; j=1, \ldots, n)$ be the $r$ output of $j$ DMU. Vector $\mathbf{X}_{j}=\left(x_{1 j}, x_{2 j}, \ldots, x_{m j}\right)^{T}$, where $\mathbf{X}_{j}(j=1, \ldots, n)$, is the vector of the input vector of unit $j$. Vector $\mathbf{Y}_{j}=\left(y_{1 j}, y_{2 j}, \ldots, y_{s j}\right)^{T}$, where $\mathbf{Y}_{j}(j=1, \ldots, n)$, is the vector of its output vector.

Let variable $v_{i}(i=1, \ldots, m)$ be the weight of $i$ input, and let variable $u_{r}(r=1, \ldots, s)$ be the weight of $r$ output. Vector $\mathbf{u}=\left(u_{1}, u_{2}, \ldots, u_{m}\right)^{T}$, where $\mathbf{u}$ is the vector of input weight. Vector $\mathbf{v}=\left(v_{1}, v_{2}, \ldots, v_{s}\right)^{T}$, where $\mathbf{v}$ is the vector of output weight.

The efficiency index of unit $j$ can be represented as $h_{j}=\left(u^{T} \mathbf{Y}_{\boldsymbol{j}}\right) /\left(v^{T} \mathbf{X}_{\mathbf{j}}\right), j=1,2, \ldots, n$, and the mathematical model for evaluating unit $j_{0}$ can be defined as

$$
\begin{aligned}
& \max =\frac{u^{T} \mathbf{Y}_{j_{0}}}{v^{T} \mathbf{X}_{j_{0}}}, \\
& \text { s.t. }\left\{\begin{array}{l}
\frac{u^{T} \mathbf{Y}_{j_{0}}}{v^{T} \mathbf{X}_{j_{0}}} \leq 1, \quad j=1,2, \ldots, n \\
u \geq 0, v \geq 0, \quad u \neq 0 ; v \neq 0
\end{array}\right.
\end{aligned}
$$

2.1.2. A System of Input-Output Indicators. Data are selected from Wind and Institute of Public \& Environmental Affairs (IPE). The Wind is a company that is superior in the field of financial data, information, and software services in China. The IPE is a nonprofit environmental research organization registered and based in China.

Business efficiency, financial efficiency, financing efficiency, and human capital efficiency were significant factors for the management of an enterprise, and it would lead to financial distress if some of the efficiency above was low. The ecological efficiency is considered in this system, and ESG (Environment, Social, and Government) is a popular indicator to measure that efficiency. The ESG announced by various institutes today is immature, and there are some research studies on establishing the ESG indicator system. Zhao et al. [23] gave a construction of the ESG index evaluation system, which included emission rate of pollution, 


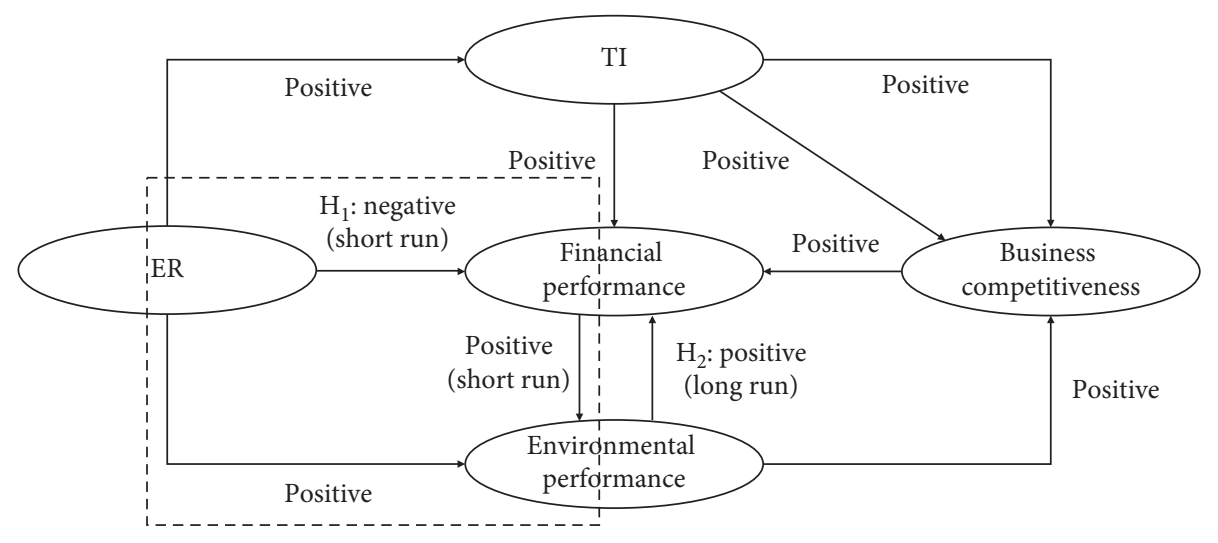

FIgURE 1: Theoretical framework.

environmental safety accidents, and charity donations. The ESG covered environmental performance, social responsibility, and enterprise governance. Business efficiency, financial efficiency, financing efficiency, human capital efficiency, and ecological efficiency are included in the input-output system. The indicators are shown in Table 1.

Business efficiency indicates the ability of management of an enterprise. The inefficient operation will lead to poor management, which may result in bankruptcy distress. Operating costs, growth rate of total assets, and growth rate of total liabilities are selected as input indicators. The output indicator is operating income, which represents the earning of an enterprise.

Financial efficiency reflects the financial condition of an enterprise. The enterprise would fail to operate if the total assets were not enough to offset the total liabilities. Asset-liability ratio, total owners' equity, total assets turnover, and turnover of fixed assets are selected as input indicators. Both earnings per share and return on the total asset are selected as output indicators.

Financing efficiency is to evaluate the efficiency of an enterprise in the process of financing. Bankruptcy can result from the failure of financing or difficulty in repayment. Total assets, currency funds, and total liabilities are selected as input indicators. Both operating income and total assets turnover are selected as output indicators.

Human capital efficiency reflects the allocation of human capital. The decline of human capital efficiency can lead to a shortfall in receipts and then brings financial distress. Employee pay payable and cash paid to and for employees are selected as input indicators. The output indicator is operating income.

Ecological efficiency is the efficiency of ecological products and services. Given the availability of data, environmental illegality and taxes are selected as input indicators. Environmental illegality is a dummy variable, and it represents whether the enterprise has environmental administrative illegal activity in the past 3 years. The outcome indicator is operating income.

\subsection{Financial Distress Warning}

2.2.1. Method: ANNs. ANNs is a mathematic model that imitates the neural network of animals; it is constructed with a mass of nodes as well as the links between nodes [24, 25]. Each node represents a function, and the link is the weight of its corresponding nodes. The process can be described as a directed graph, and each node $i$ performs the transfer function as $f_{i}$ :

$$
y_{i}=f_{i}\left(\sum_{j=1}^{n} w_{i j} x_{j}-\theta_{i}\right),
$$

where variable $y_{i}$ is the output from node $i$, variable $x_{j}$ is a $j$ th node, variable $w_{i j}$ is the weight linking nodes $i$ and $j$, and variable $\theta_{i}$ is the threshold or bias value of the nodes. The transfer function $f_{i}$ is usually nonlinear, such as the Heaviside function, sigmoid function, and Gaussian function.

2.2.2. Selection of Indicators. The financial ratios applied in financial distress warnings are various. According to Mselmi et al. [16], financial ratios selected as initial features for financial distress warnings included liquidity, management, profitability, size, solvability and stability, structure, liabilities, growth, and cash flow. Also, indicators selected [26-28] for our study are shown in Table 2.

2.3. Data. 72 listed companies in China that have been special treated (ST) after ER are selected for the study. There are 10 from Anhui Province, 7 from Jiangxi Province, 25 from Shanghai City, 10 from Hebei Province, 18 from Liaoning Province, and 2 from Guizhou Province. The ER in Anhui Province refers to the Xin'anjiang River basin ecocompensation. The ER in Jiangxi Province, Shanghai City, Liaoning Province, and Guizhou Province were meant for drinking water protection, while the ER in Hebei Province 
TABLE 1: System of input-output indicators.

\begin{tabular}{|c|c|c|c|}
\hline Dimension & Input indicators & Output indicators & Source \\
\hline Business efficiency & $\begin{array}{c}\text { Operating costs (CNY) } \\
\text { Growth rate of total assets (\%) } \\
\text { Growth rate of total liabilities (\%) }\end{array}$ & Operating income (CNY) & Wind \\
\hline Financial efficiency & $\begin{array}{c}\text { Asset-liability ratio (\%) } \\
\text { Total owners' equity (CNY) } \\
\text { Total assets turnover (time) } \\
\text { Turnover of fixed assets (time) }\end{array}$ & $\begin{array}{c}- \\
\text { Earnings per share (CNY) } \\
\text { Return on total asset }(\%) \\
-\end{array}$ & Wind \\
\hline Financing efficiency & $\begin{array}{c}\text { Total assets (CNY) } \\
\text { Currency fund (CNY) } \\
\text { Total liabilities (CNY) }\end{array}$ & $\begin{array}{l}\text { Operating income }(\mathrm{CNY}) \\
\text { Total assets turnover }(\%)\end{array}$ & Wind \\
\hline Human capital efficiency & $\begin{array}{c}\text { Employee pay payable (CNY) } \\
\text { Cash paid to and for employees (CNY) }\end{array}$ & Operating income (CNY) & Wind \\
\hline Ecological efficiency & $\begin{array}{c}\text { Environmental illegality }(\text { yes }=1 ; \text { no }=0) \\
\text { Taxes }(\mathrm{CNY})\end{array}$ & Operating income (CNY) & Wind IPE \\
\hline
\end{tabular}

Note: CNY is the abbreviation of Chinese yuan. IPE is the abbreviation of Institute of Public and Environmental Affairs.

TABLE 2: Selection of indicators.

\begin{tabular}{lcc}
\hline Indicator & Variable & Formula \\
\hline Return on equity (\%) & roe & Net profit/owners' equity \\
Total assets turnover (\%) & tato & Total liabilities/total assets \\
Asset-liability ratio (\%) & $a l r$ & Total inventory/current assets \\
Ratio of inventory (\%) & $r i$ & Cash received from the sale/total assets \\
Receivable ratio (\%) & $r r$ & Total accounts receivable/current assets \\
Net cash flow per share (CNY) & $n c f$ & Net cash flow from operations/total equity \\
\hline
\end{tabular}

was meant to water resource protection. The programs above are related to the protection of water, and they can avoid the error caused by the heterogeneity of ER.

To eliminate the error caused by sample selection, another 72 list companies that did not suffer from ST are selected from the same region as well as the same industry (Table 3).

The study aims at improving the accuracy of the financial distress warning model by considering ecological efficiency and only target enterprises that are influenced by the ER of water protection schemes. Suppose that an enterprise suffered from ST at $T$ year, data from $T-3$ year are selected for evaluating the efficiency, and data from $T-1, T-2$, and $T-3$ year are selected for financial distress warning.

\section{Results and Discussion}

3.1. Results. The comparison of the evaluation of business efficiency, financial efficiency, financing efficiency, human capital efficiency, and ecological efficiency is shown in Figure 2.

For business efficiency ( $a$ ) and human capital efficiency (d), the mean value, position point, and limitation of ST enterprises are higher than non-ST enterprises. For financial efficiency $(b)$ and ecological efficiency (e), the mean value, position point, and limitation of ST enterprises are lower than non-ST enterprises. For financing efficiency, the mean value, position point, and limitation of ST enterprises are similar to non-ST enterprises. It can be inferred that ecological efficiency is necessary for enterprises.

The Levene variance equality test and independentsample Student's test (T-test) are applied for further study (Table 4). In the Levene variance equality test, only business efficiency has a significant difference in ST enterprises and non-ST enterprises. In the $T$-test, indicators are of significant difference in ST enterprises and non-ST enterprises at $1 \%$, except financing efficiency. It indicates that the ability of warning financial distress of a single dimension is out of accuracy and that combination of several dimensions of efficiency is necessary.

The Levene variance equality test and $T$-test of financial ratios are shown in Table 5 . In the Levene variance equality test, total assets' turnover is of significant difference in ST enterprises and non-ST enterprises at $1 \%$, and the ratio of inventory is of significant difference in ST enterprises and non-ST enterprises at 5\%. In the T-test, both total assets' turnover and asset-liability ratio are of significant difference in ST enterprises and non-ST enterprises at $1 \%$.

Results of ANNs are shown in Figure 3. In year $T$-1, the average accuracy of the group "without ecological efficiency" is the highest, indicating that a system combining business efficiency, financial efficiency, financing efficiency, and human capital efficiency is most suitable to warn financial distress in the 1 year before ST. In years $T-2$ and $T-3$, the average accuracy of the group "with ecological efficiency" is the highest, indicating that a system combining business 
TABLE 3: Selection of samples.

\begin{tabular}{lcc}
\hline Province/municipality & Time of ER & Number of enterprises that will be ST after the time of ER \\
\hline Anhui Province & 2012 & 10 \\
Jiangxi Province & 2008 & 7 \\
Shanghai City & 2009 & 25 \\
Hebei Province & 2008 & 10 \\
Liaoning Province & 2007 & 18 \\
Guizhou Province & 2012 & 2 \\
Total & - & 72 \\
\hline
\end{tabular}

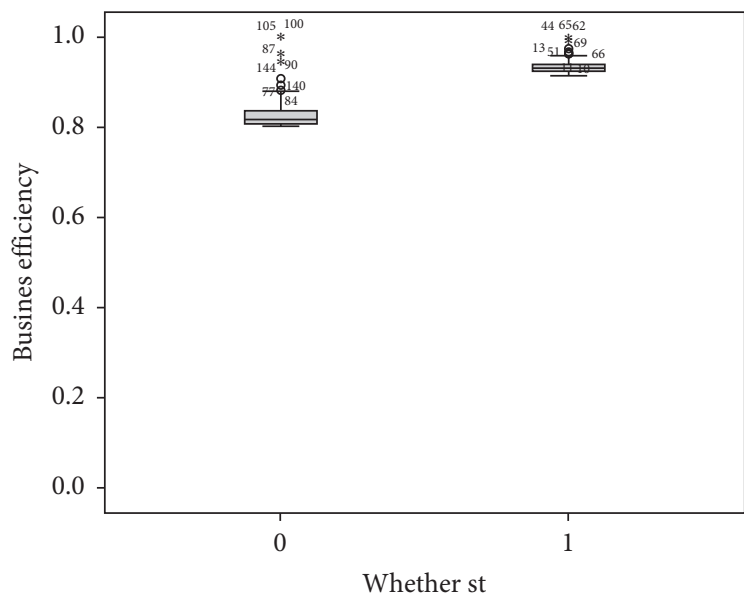

(a)

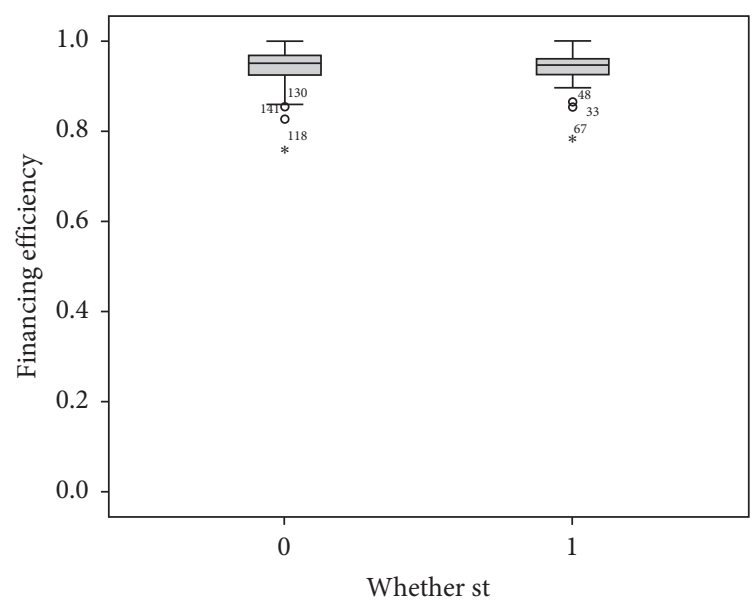

(c)

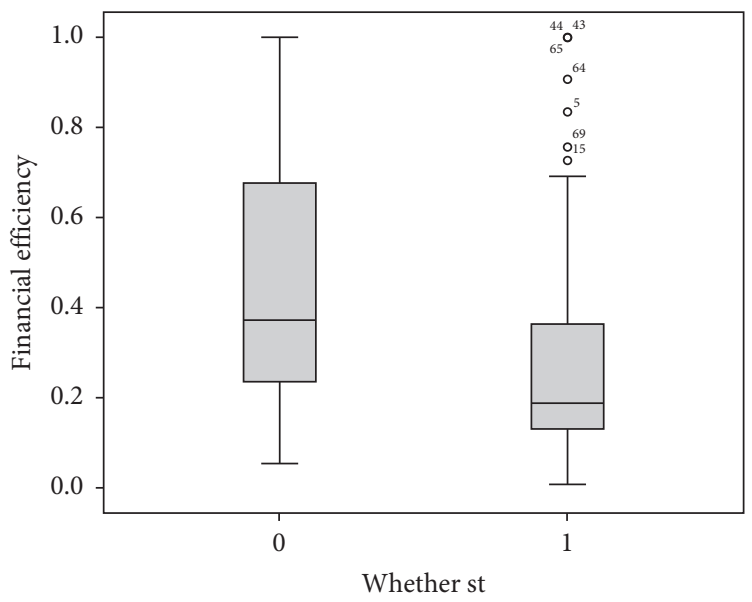

(b)

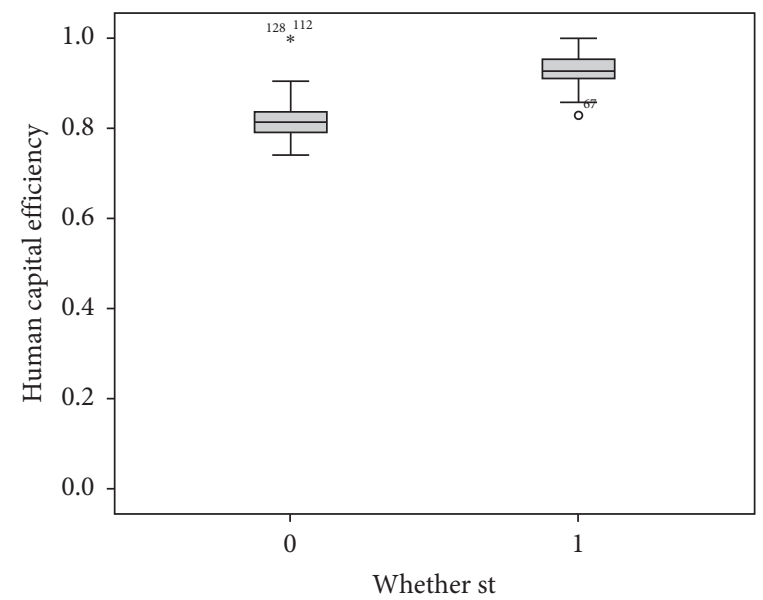

(d)

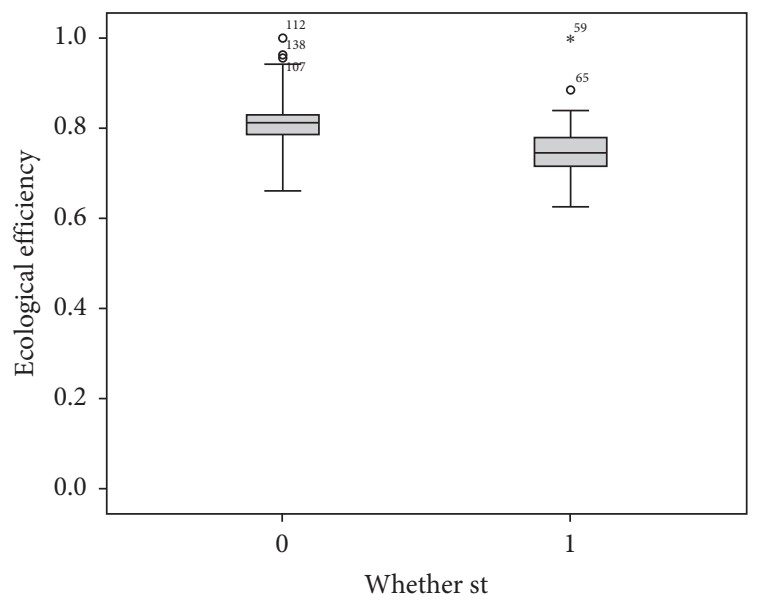

(e)

FIGURE 2: Comparison of ST enterprises and non-ST enterprises' inefficiency. 


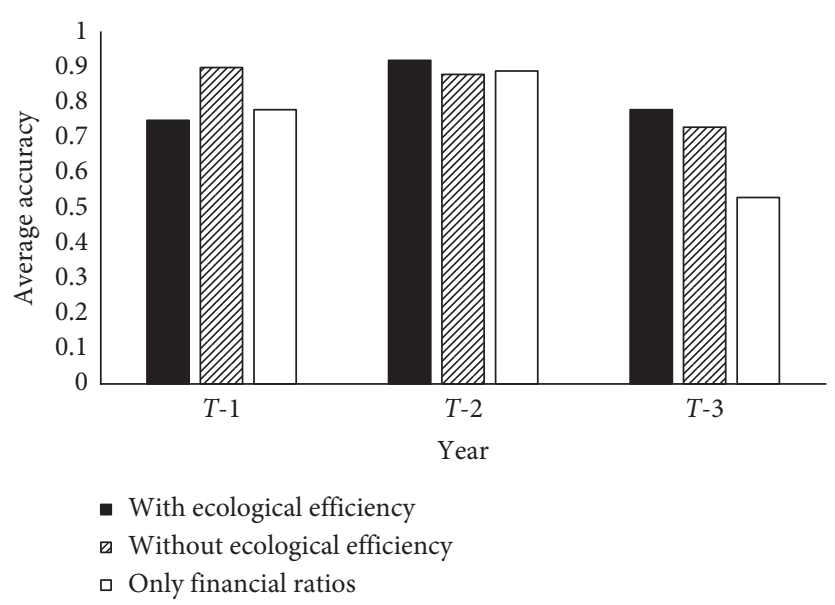

FIgURE 3: Comparison of average accuracy of ANNs.

TABLE 4: Levene variance equality test and T-test of efficiency indicators.

\begin{tabular}{lccrc}
\hline & \multicolumn{2}{c}{ Levene variance equality test } & \multicolumn{2}{c}{ T-test } \\
& $F$ & Sig. & Mean difference & Sig. \\
\hline Business efficiency & 19.36 & 0.00 & 0.10 & 0.00 \\
Financial efficiency & 0.24 & 0.63 & -0.13 & 0.01 \\
Financing efficiency & 0.45 & 0.50 & 0.00 & 0.98 \\
Human capital efficiency & 1.57 & 0.21 & 0.11 & 0.00 \\
Ecological efficiency & 1.71 & 0.19 & -0.05 & 0.00 \\
\hline
\end{tabular}

TABLE 5: Levene variance equality test and $T$-test of financial ratios.

\begin{tabular}{|c|c|c|c|c|c|}
\hline \multirow[t]{2}{*}{ Indicator } & \multirow[t]{2}{*}{ Variable } & \multicolumn{2}{|c|}{$\begin{array}{c}\text { Levene variance } \\
\text { equality test }\end{array}$} & \multicolumn{2}{|c|}{$T$-test } \\
\hline & & $F$ & Sig. & Mean difference & Sig. \\
\hline Return on equity (\%) & roe & 1.11 & 0.30 & -1.80 & 0.79 \\
\hline Total assets turnover (\%) & tato & 5.58 & 0.02 & -0.28 & 0.00 \\
\hline Asset-liability ratio (\%) & alr & 0.04 & 0.85 & 10.71 & 0.01 \\
\hline Ratio of inventory (\%) & $r i$ & 4.03 & 0.05 & 0.02 & 0.63 \\
\hline Receivable ratio $(\%)$ & $r r$ & 0.07 & 0.79 & 0.01 & 0.73 \\
\hline Net cash flow per share (CNY) & $n c f$ & 0.10 & 0.75 & -0.21 & 0.31 \\
\hline
\end{tabular}

efficiency, financial efficiency, financing efficiency, human capital efficiency, and ecological efficiency is most suitable to warn financial distress in the 2 and 3 years before ST.

Figure 3 also shows that, whatever the warning system is, the financial distress warning has the highest accuracy in the 2 years before ST. Besides, the accuracy of the group "with ecological efficiency" displays better than the other two groups in the long run (more than 1 year). Furthermore, the accuracy of the group "only financial ratios" has a sharp decline in year $T-3$, suggesting that it fails to warn the financial distress in the long run.

According to the analysis above, we conclude that the system including ecological efficiency displays better in predicting financial distress, and it is most suitable to warn financial distress in the 2 and 3 years before ST. The result provides a more accurate system for financial distress warning and enriches the theoretical research in evaluating financial distress. Also, it alerts that the companies would better consider ecological influence when assessing their risk of getting into financial distress.

3.2. Robustness Test. The logit model is applied to test the robustness of the result. The logit model has the following basic form:

$$
\operatorname{logit} P_{i}=\ln \left(\frac{P_{i}}{1-P_{i}}\right)=\alpha_{i}+\sum_{j=1}^{k} \beta_{i j} X_{i j}
$$

where $P_{i}$ represents the probability of financial distress of firm $i$, and it is a dummy variable. $P_{i}$ is equal to 1 if the enterprise $i$ is ST and equal to 0 otherwise. $\alpha_{i}$ and $\beta_{i}$ are parameters to be estimated. Vector $X_{i j}$ includes financial ratios and ecological efficiency indicators, that are return on equity (roe), total assets' turnover (tato), asset-liability ratio 
TABLE 6: Results of the logit model.

\begin{tabular}{lccc}
\hline & Year $T-1$ & Year T-2 & Year T-3 \\
\hline roe & $-0.01^{* * *}(-3.23)$ & $-0.11^{* * *}(-3.50)$ & $3.65 e-03(0.48)$ \\
tato & $-0.86^{* * *}(-2.44)$ & $-0.64^{*}(-1.63)$ & $-1.12^{* * *}(-2.77)$ \\
alr & $0.05^{* * *}(3.38)$ & $0.04^{*}(2.72)$ & $0.03^{* * *}(3.26)$ \\
$r i$ & $0.97(0.95)$ & $-0.07(-0.05)$ & $-0.52(-0.54)$ \\
$r r$ & $-1.35(-0.99)$ & $-2.51(-1.44)$ & $-1.62(-1.20)$ \\
$n c f$ & $-0.58(-1.34)$ & $-0.10(-0.32)$ & $-0.02(-0.09)$ \\
Environmental illegality & $1.25^{* * *}(2.18)$ & $0.58(0.80)$ & $0.64(1.20)$ \\
Taxes & $-0.64^{* * *}(-3.60)$ & $-0.48^{* *}(-2.37)$ & $-0.34^{* * *}(-2.87)$ \\
cons & $7.96^{* * *}(3.02)$ & $6.41^{*}(1.91)$ & $5.02^{* * *}(2.65)$ \\
Wald chi ${ }^{2}$ & $36.65^{* * *}$ & $24.36^{* * *}$ & $22.38^{* * *}$ \\
Log pseudolikelihood & -51.2268 & -65.4090 & -80.0352 \\
\hline
\end{tabular}

Note: ${ }^{* * *},{ }^{* *}$, and ${ }^{*}$, respectively, indicate that the estimated coefficients are significant at levels $1 \%, 5 \%$, and $10 \%$. The values in brackets are $z$ values.

(alr), ratio of inventory (ri), receivable ratio (rr), net cash flow per share (ncf), environmental illegality, and taxes.

Variable environmental illegality is positive and significant at $1 \%$ in year $T-1$. It suggests that if an enterprise violates the environmental regulations, it is possible to face ST in one year. Variable taxes is negative and significant in years $T-1, T-2$, and $T-3$. It suggests that the more the taxes an enterprise pays, the less possibility the enterprise be ST. The results indicate that the behavior of observing disciplines and obeying laws will help the enterprises escape from the distress of bankruptcy (Table 6).

3.3. Discussion. It can be inferred that environmental illegality can lead to a sudden ST for the enterprise. The enterprise is likely to observe the rules when facing the ER from the government, and the activity of environmental illegality is usually not intended. In that case, the failure of adjusting the industry structure may be a crucial factor in resulting in environmental illegality. Financial support and technical assistance will help to avoid companies from trapped in financial distress $[29,30]$.

Finance can provide diversified channels for investment and financing, to guarantee the sustainability of environmental protection. The financial industry is one of the main sources of loan financing for the society. The strengthening of ecological finance not only can promote the diversification of financing methods and meet the demand for ecological funds but also can supervise the usage of finance. It can help to achieve the purpose of improving the ecological environment and promoting economic development. Policy-based finance is supposed to be an important mean when the financial market fails to allocate resource [31]. Green financial instruments, especially green credit, are confirmed to promote economic growth [32], industrial transformation [33], and TI [34]. In a word, the function of green finance should be motivated, and the sustainability of the environment, economy, and society is the goal.

In China, the ecological efficiency of enterprises is easy to be ignored in the process of corporate statistics, and only a few indicators can be excerpted. The survey on business efficiency, financial efficiency, financing efficiency, and human capital efficiency has been comprehensive today, which contributes to the research of establishing a multidimensional evaluation system that including the indicators above. However, the data missing of ecological efficiency prevent the research to establish a more reasonable system for financial distress warning.

\section{Conclusion}

Accurate financial distress warning improves the decisionmaking of company management and benefits some other stakeholders. Based on the data of listed companies, five dimensions of indicators are selected to measure the accuracy of the evaluation system, including business efficiency, financial efficiency, financing efficiency, human capital efficiency, and ecological efficiency. DEA is applied to evaluating the efficiency of each dimension, and the results indicate that a single dimension or a single financial ratio can hardly predict the financial condition. ANNs are applied to measure the accuracy of the three kinds of evaluation system: with ecological efficiency, without ecological efficiency, and only financial ratios. The results suggest that the participation of ecological efficiency improves the evaluation system of financial distress warnings, and its accuracy is much better than the traditional evaluation systems in the long run. Besides, the logit model is applied to test the results, indicating that the behavior of observing environmental regulation will prevent enterprises from getting into financial distress.

The factors for the financial distress of an enterprise are various, and ecological performance that is influenced by ER is one of them. It is indisputable that TI is the core of an enterprise's competitiveness, and green finance can accelerate that process.

\section{Data Availability}

The Wind and IPE data used to support the findings of this study are included within the article.

\section{Conflicts of Interest}

The authors declare that they have no conflicts of interest. 


\section{Acknowledgments}

This research was supported by the National Natural Science Foundation of China (Grant no. 71603117).

\section{References}

[1] S. Chen and J. Golley, "Green' productivity growth in China's industrial economy," Energy Economics, vol. 44, pp. 89-98, 2014.

[2] L. L. Guo, Y. Qu, and M.-L. Tseng, "The interaction effects of environmental regulation and technological innovation on regional green growth performance," Journal of Cleaner Production, vol. 162, pp. 894-902, 2017.

[3] M. Tang, G. Walsh, D. Lerner, M. A. Fitza, and Q. Li, “Green innovation, managerial concern and firm performance: an empirical study," Business Strategy and the Environment, vol. 27, no. 1, pp. 39-51, 2018.

[4] M. Hang, J. Geyer-Klingeberg, and A. W. Rathgeber, "It is merely a matter of time: a meta-analysis of the causality between environmental performance and financial performance," Business Strategy and the Environment, vol. 28, no. 2, pp. 257-273, 2019.

[5] S.-P. Chuang and S.-J. Huang, "The effect of environmental corporate social responsibility on environmental performance and business competitiveness: the mediation of green information technology capital," Journal of Business Ethics, vol. 150, no. 4, pp. 991-1009, 2018.

[6] H. Zameer, Y. Wang, and H. Yasmeen, "Reinforcing green competitive advantage through green production, creativity and green brand image: implications for cleaner production in China," Journal of Cleaner Production, vol. 247, p. 15, 2020.

[7] W. Jin, H.-Q. Zhang, S.-S. Liu, and H.-B. Zhang, "Technological innovation, environmental regulation, and green total factor efficiency of industrial water resources," Journal of Cleaner Production, vol. 211, pp. 61-69, 2019.

[8] N. Shen, H. Liao, R. Deng, and Q. Wang, "Different types of environmental regulations and the heterogeneous influence on the environmental total factor productivity: empirical analysis of China's industry," Journal of Cleaner Production, vol. 211, pp. 171-184, 2019.

[9] M. C. Cuerva, Á. Triguero-Cano, and D. Córcoles, "Drivers of green and non-green innovation: empirical evidence in LowTech SMEs," Journal of Cleaner Production, vol. 68, pp. 104-113, 2014.

[10] G. Cecere, N. Corrocher, and M. L. Mancusi, "Financial constraints and public funding of eco-innovation: empirical evidence from European SMEs," Small Business Economics, vol. 54, no. 1, pp. 285-302, 2020.

[11] Z. Huang, G. Liao, and Z. Li, "Loaning scale and government subsidy for promoting green innovation," Technological Forecasting and Social Change, vol. 144, no. 4, pp. 148-156, 2019.

[12] D. Zhang, Z. Rong, and Q. Ji, "Green innovation and firm performance: evidence from listed companies in China," Resources, Conservation and Recycling, vol. 144, pp. 48-55, 2019.

[13] J. Sun and H. Li, "Financial distress prediction using support vector machines: ensemble vs. individual," Applied Soft Computing, vol. 12, no. 8, pp. 2254-2265, 2012.

[14] Z. Yang, W. You, and G. Ji, "Using partial least squares and support vector machines for bankruptcy prediction," Expert Systems with Applications, vol. 38, no. 7, pp. 8336-8342, 2011.
[15] G. Zhang, M. Y. Hu, B. Eddy Patuwo, and D. C. Indro, "Artificial neural networks in bankruptcy prediction: general framework and cross-validation analysis," European Journal of Operational Research, vol. 116, no. 1, pp. 16-32, 1999.

[16] N. Mselmi, A. Lahiani, and T. Hamza, "Financial distress prediction: the case of French small and medium-sized firms," International Review of Financial Analysis, vol. 50, pp. 67-80, 2017.

[17] S. Shanmugathas and K. Ashoka, "Material sourcing in a strategic way: evaluation of consequences on the organizational performance," Journal of Logistics, Informatics and Service Science, vol. 6, no. 1, pp. 69-86, 2019.

[18] M. A. Safayet, M. H. Islam, and S. Ahmed, "A case study on risk management in existing construction project in Bangladesh," Journal of Logistics, Informatics and Service Science, vol. 5, no. 1, pp. 1-16, 2018.

[19] E. Comăniță, P. Cozma, I. Simion, M. Roşca, and M. Gavrilescu, "Evaluation of eco-efficiency by multicriteria decision analysis case study of eco-innovated and ecodesigned products from recyclable waste," Environmental Engineering and Management Journal, vol. 17, no. 8, pp. 1791-1804, 2018.

[20] M. E. Porter and C. V. D. Linde, "Toward a new conception of the environment-competitiveness relationship," Journal of Economic Perspectives, vol. 9, no. 4, pp. 97-118, 1995.

[21] T. Hovardas, "Two paradoxes with one stone: a critical reading of ecological modernization," Ecological Economics, vol. 130, pp. 1-7, 2016.

[22] A. Charnes, W. W. Cooper, and E. Rhodes, "Measuring the efficiency of decision making units," European Journal of Operational Research, vol. 2, no. 6, pp. 429-444, 1978.

[23] C. H. Zhao, Y. Guo, J. H. Yuan et al., "ESG and corporate financial performance: empirical evidence from China's listed power generation companies," Sustainability, vol. 10, no. 8, p. 18, 2018.

[24] J. B. Kim, "Implementation of artificial intelligence system and traditional system: a comparative study," Journal of System and Management Sciences, vol. 9, no. 3, pp. 135-146, 2019.

[25] H. M. Afify, K. K. Mohammed, and A. E. Hassanien, "Multiimages recognition of breast cancer histopathological via probabilistic neural network approach," Journal of System and Management Sciences, vol. 1, no. 2, pp. 53-68, 2020.

[26] H.-Y. Wu, A. Tsai, and H.-S. Wu, "A hybrid multi-criteria decision analysis approach for environmental performance evaluation: an example of the TFT-LCD manufacturers in Taiwan," Environmental Engineering and Management Journal, vol. 18, no. 3, pp. 597-616, 2019.

[27] F. Georgescu, B. Cozmâncă, A.-M. Cazacu, and A. Cojocaru, "Fiscal and income incentives trigger imbalances in a partly functional market economy," Economic Computation and Economic Cybernetics Studies and Research, vol. 54, no. 2, pp. 5-22, 2020.

[28] H. Rok Yim, "Firm performances within transition countries: pro-EU group vs. pro-Russia group," Economic Computation and Economic Cybernetics Studies and Research, vol. 54, no. 2, pp. 165-179, 2020.

[29] M. S. Sadat and K. Dervis, "Investigating the nexus between political risk and economic risk: a wavelet coherence analysis for Greece, Albania, Bulgaria and Romania," Economic Computation and Economic Cybernetics Studies and Research, vol. 54, no. 4, pp. 283-299, 2020.

[30] M. Yeum, K. Wee, and W. Bang, "The effect of internal marketing on competitive advantage as organizational 
coaching-the mediating effect of service innovation," Journal of System and Management Sciences, vol. 10, no. 1, pp. 62-71, 2020.

[31] G. Kabango, "Financial liberalization and industry structure nexus: an investigation using dynamic heterogeneous panels from malawian data, " $\mathrm{PhD}$ Thesis, University of Glasgow, Glasgow, Scotland, 2009.

[32] I. Alexander and C. Mayer, "Banks and securities markets: corporate financing in Germany and the United Kingdom," Journal of the Japanese and International Economies, vol. 4, no. 4, pp. 450-475, 1990.

[33] A. Ilyina and R. Samaniego, "Technology and financial development," Journal of Money, Credit and Banking, vol. 43, no. 5, pp. 899-921, 2011.

[34] L. Benfratello, F. Schiantarelli, and A. Sembenelli, "Banks and

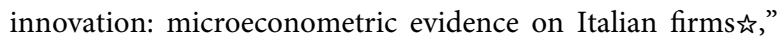
Journal of Financial Economics, vol. 90, no. 2, pp. 197-217, 2008. 